\title{
Progress of the Digital Silk Roads project
}

Kinji Ono ${ }^{1}$, Takeo Yamamoto ${ }^{2}$, Toshiro Kamiuchi ${ }^{3}$, Asanobu Kitamoto ${ }^{4}$, Frederic Andres $^{5}$, Sonoko Sato ${ }^{6}$, Elham Andaroodi ${ }^{7}$

1, 2,3,4,5, 6,7 National Institute of Informatics (NII)

${ }^{2,5,7}$ The Gradnate University of Advanced Studies (SOKENDAI)

${ }^{3}$ Hitachi Co.Ltd.

\section{ABSTRACT}

NII launched the Digital Silk Roads (DSR) project in cooperation with UNESCO as an international joint research project at NII in April 2001. In December 2001, at a the Tokyo symposium for Digital Silk Roads jointly organized by NII and UNESCO, the Tokyo Declaration was issued. The second International Symposium for the Digital Silk Roads was held at Nara in December 2003. A memorandum of understanding (MOU) between UNESCO and NII was signed by the Directors General of UNESCO and NII in March 2003. Under this MOU, the Digital Silk Roads Initiative Framework (DSRIF) was established as a coordination mechanism for promotion of the Project. The Bamiyan Remains in Afghanistan were archived as the Bamiyan Virtual Museum before being dynamited. Digital archiving of various historical documents, including rare books in the possession of the Toyo Bunko in Tokyo, was carried out. An Advanced Scientific Portal for International Cooperation on the Digital Silk Roads(ASPICO-DSR) was developed to provide a platform for collaboration of Digital Silk Roads studies. Ontology of caravanserais in Central Asia and 3D virtual restoration of the Citadel of Bam are currently being researched.

This paper presents the progress of the Digital Silk Roads project conducted at NII, reporting on the objectives, targeted areas, program concept, architecture, and implementation by reviewing its past achievements.

Ch.1 gives an introductory remarks by K.Ono. Ch.2 overviews of the Digital Silk Roads project by K.Ono Ch.3 describes the digital archive of the rare books on Silk Road in the possession of the Toyo Bunko by T.Yamamoto and S.Sato. Ch.4 presents the virtual restoration of the Bamiyan ruins using DIS technology by T.Kamiuchi. Ch.5 report on the DSR portal sites and its structure by A. Kitamoto . Ch.6 describes the architecture and metadata management of the ASPICO portal by K.Ono. Ch.7 describes resources management techniques by F.Andres. Ch.8 discusses Spacial-Lexical Knowledge Model for the Silk Roads caravanserais by E. Andaroodi. Ch.9 concludes this report with a discussion of perspectives on the future by K.Ono

\section{KEYWORDS}

DSR, DSRIF, Digital Archive, Silk Road, Toyo Bunko, Bamiyan, Virtual Museum, Annotation, ASPICO, Portal, Ontology, Caravanserais

Received December 16, 2004; Revised February 7, 2005; Accepted February $8,2005$.

\{1) ono, 2)ty, 4)kitamoto, 5)andres, 6) sonoko\}@nii.ac.jp

3) Kamiuchi@system. hitachi.co.jp, 7) elham@grad.nii.ac.jp 


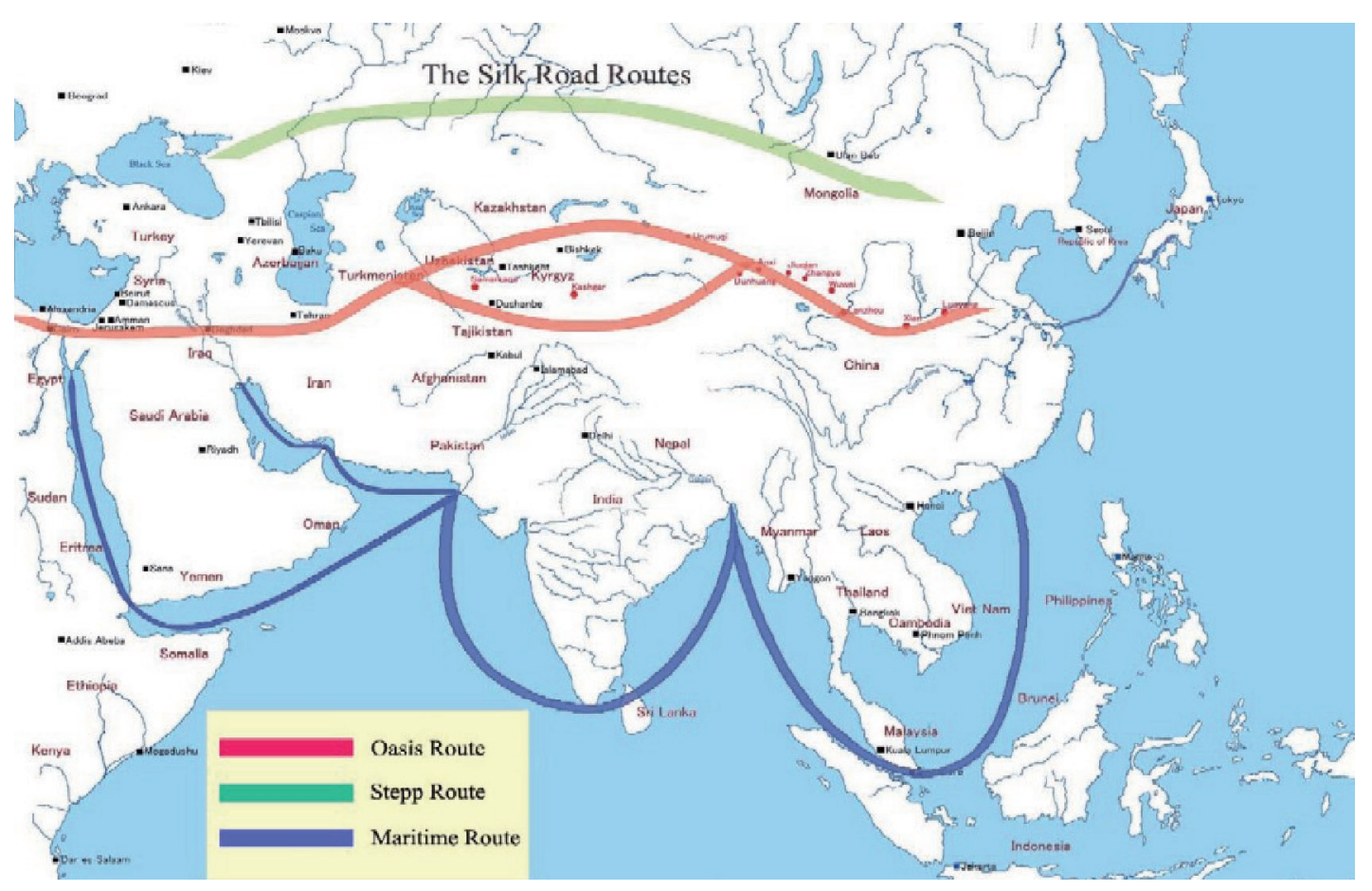

Figure 2-1. MAP of the Silk Road Routes

\section{Introduction}

At present, a great deal of historical, cultural, and natural heritage is on the verge of disappearing due to factors including wars, disasters, and simply the passage of time.

At the same time, current information technologies provide opportunities for recording, archiving, and disseminating digitized information on cultural resources, creating space for intercultural dialogue and new cultural expressions.

NII (National Institute of Informatics) has launched the Digital Silk Roads (DSR) project in April 2001 in cooperation with UNESCO (United Nations Educational, Scientific, and Cultural Organization). The project aims to create a digital archive of cultural heritage in the Silk Road region, and establish a network collaboration system by linking advanced information technology and cultural sciences.

The Tokyo Symposium for Digital Silk Roads, the project's first major international conference, was held in December 2001. The Tokyo Declaration, adopted at the symposium, summarized the discussion and formed a basis for the launch of a full-fledged international collaborative project "Digital Silk Roads", jointly led by NII and UNESCO. [1]

This article reports on the progress of the "Digital Silk Roads", referencing our past achievements. [2][9]

If the DSR project proves successful, it will enable people to freely explore and experience some of the Silk Road Heritage sites without actually visiting them, which have been merely a dream for many decades. We hope that the Digital Silk Roads project will significantly enhance global cultural diversity.

\section{The Digital Silk Roads project}

As is widely known, the "Silk Road" refers to the numerous trade routes that served to carry silk and other commodities across the Eurasia continent over past centuries.

For centuries, it has served as a major stage for historical events and for cultural exchanges. Vast amounts of information concerning science, technology, art, and religion have been transferred along the Road, influencing many different peoples and their civilizations in the region.

Among them, the most famous are the Desert or Oasis Route from Xian to Kashgar in China, the Steppe Route running through Central Asia, and the Maritime Route from Venice to Osaka.

Figure 2-1 shows a map of the "Silk Road", with these routes represented by various lines.

The invaluable cultural and natural heritage that still remains along the Silk Roads is certainly a significant witness to human history and should be preserved and 


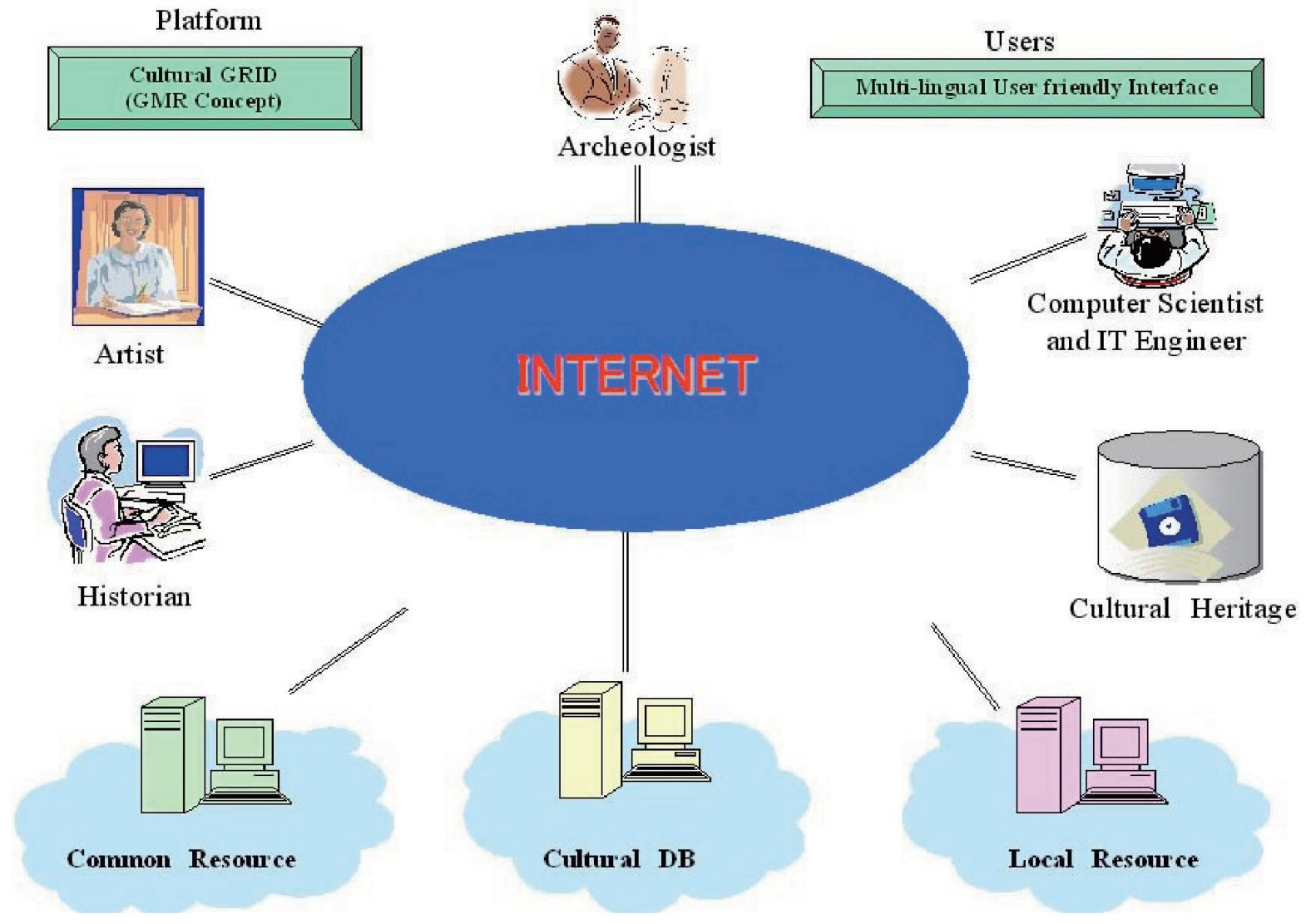

Fig. 2-2 GMR concept

passed on to future generations as a great common asset of all mankind.

\subsection{Background}

A UNESCO project called "Integral Study of the Silk Roads: Roads of Dialogue", began in 1988. It mobilized numerous experts and institutions involved in research on these routes and succeeded in creating an extensive network for Silk Roads studies. The project resulted in a variety of seminars, research programs, books, films, videos, and photos from expeditions.[7]

Based on such achievements, the DSR project tries to link advanced information technology and cultural studies in order to further enhance interest in precious cultural assets along the Silk Roads. DSR aims to advance the knowledge accumulated through past Silk Road studies with the help of digital technology and promote the use of such knowledge not only among academia but also among the general public the worldover.[5][6]

\subsection{Objectives and Goal of the DSR project}

The project seeks to establish a new approach to Silk Road studies, fusing cultural sciences and information technology through digital archiving and network collaboration.[8]

The Digital Silk Roads project is aiming to create a digital archive of the geographically dispersed Silk Road heritage and develop a system to facilitate the use of the digital archive, based on the concept of a Global Multimedia Repository (GMR) featuring the integration of advanced information technology and cultural themes in distributed environments. In addition, the project aims to establish a means to conserve Silk Road heritage in digital form and make it available to people around the world through digital archiving. The project is carried out through international collaboration and cooperation between Information Technology experts and cultural specialists.[5][6]

The goal of the DSR project is to create digital archives of geographically dispersed cultural heritage contents along the Silk Roads through Internet collaboration and to make them available for retrieval and sharing world-wide. That is to lay the foundation of a 
new concept of Silk Road studies in the 21st centuries through the Digital Silk Roads and create a Virtual Museum from Silk Roads heritage resources.

Following this, the project will digitize cultural heritage materials in the possession of UNESCO, as well as those of, some other organizations and individuals, and develop an information infrastructure aimed at fully utilizing such contents.

Finally, building on this foundation, the project will expand its scope to include other major Silk Road cultural heritage sites with a view to completing the Digital Silk Roads Museum in the future.[9]

\subsection{Program Concept and Approach}

We have proposed the concept of a GMR (Global Multimedia Repository), which is designed to solve a number of problems concerning the preservation and dissemination of historical and cultural resources. We initially proposed this idea at the Tokyo Symposium for Digital Silk Roads, held in December 2001. [1],[3]

GMR is a large repository of multimedia cultural resources and can be compared to, an information storage platform where various digitized multimedia materials can be stored and utilized by a wide variety of parties who involved in research and educational activities related to the heritage of the Silk Road.

In order to protect the Silk Roads' -millenarian cultural heritage-, we intend to gather Silk Roads experts, together with information technology researchers, to build digital archives accessible from anywhere, by anyone. Toward this end, a Web-based portal solution will be employed to create, analyze and present the digital heritage database through a standard browser.

Cultural GRID is the new resource management middleware that will be used to realize this concept. It will provide deep resource for the creation of Web sites, museum exhibitions, and educational materials in the forms of CD-ROMs or DVDs. Implementing the GMR concept is a big challenge, and will require building up capabilities for the storing, accessing, and retrieving of large volumes of multilingual multimedia contents related to the Silk Roads.

Figure 2-2 shows the GMR concept we are proposing.

\subsection{Project organization}

In cooperation with relevant organizations, the project is being led by NII and UNESCO, with participation by a number of scholars and experts from various disciplines who have taken an interest in digitally archiving Silk Roads heritage materials.

Among them are the DIS group of Hitachi Corpora- tion, the Toyo Bunko, and Kyoto University's Center for Southeast Asian Studies (CSEAS) in Japan.

A research team at the University of Michigan and the ECAI group at the University of California, Berkley, and University of Hawaii, in the United States, the Ecole d'Architecture Paris Val de Seine in France, the Asian Institute of Technology in Thailand, the Iranian Cultural Heritage and Tourism Organization(ICHTO) of Iran, and Tsinghua University and the Dunhuang Academy in China are also our partners.

Researchers from these organizations will work together through network collaboration, using a global the global ASPICO (Advanced Scientific Portal for International Cooperation for DSR) portal to digitally archive geographically dispersed Silk Road heritage resources.

\subsection{Project Financing}

The project has been financed mostly by a Grant-inAid for Scientific Research (KAKENHI) by Japan's Ministry of Education, Culture, Sports, Science and Technology (MEXT), a Grant-in-Aid for Publication of Scientific Research Results from the Japan Society for the Promotion of Science(JSPS), and NII's international joint research budget.

UNESCO's Information Society Division supports a travel fund for UNESCO delegates to participate the International Symposium for Digital Silk Roads.

\subsection{Project History}

Since the launch of the Digital Silk Roads project, the following events have taken place as shown in Figure 2-3;

1) Launch of the DSR project

The project was initially launched as an international joint research project at NII in April 2001. In December 2001, the Tokyo Symposium for Digital Silk Roads was jointly organized by NII, UNESCO, and the Japanese National Commission for UNESCO, to review the results of past Silk Road studies and discuss the feasibility of Digital Silk Roads.

The Tokyo Declaration was issued at the close of the symposium. In December 2003, the second international symposium for Digital Silk Roads was held at Nara to present and discuss current and future activities.

2) MOU between UNESCO and NII

A memorandum of understanding (MOU) between UNESCO and NII was signed in March 2003 by the Directors General of UNESCO and NII. In March 2003, the full-fledged international collaborative DSR project was launched with the conclusion of the MOU 


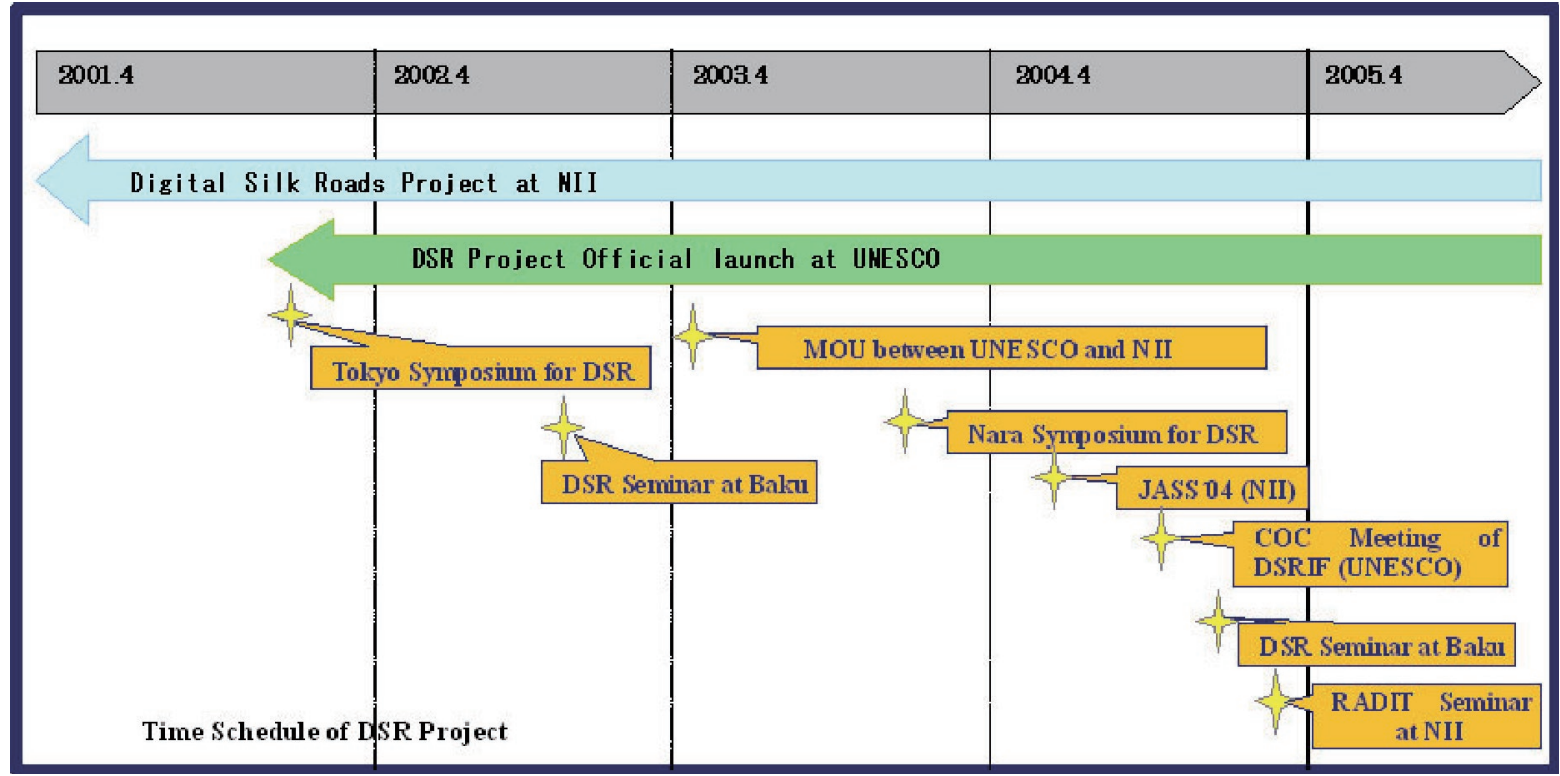

Fig. 2-3 Project History of DSR project

between NII and UNESCO. NII sent an expert to a training seminar related to Digital Silk Roads in Baku, Azerbaijan, in October 2002.

\section{3) DSRIF}

The Digital Silk Roads Initiative Framework (DSRIF) was set up under the MOU as a coordination mechanism to carry out the DSR project. DSRIF is an international collaborative framework functioning in interdisciplinary domains of activities with a far-reaching mandate to promote effective digital storage, restoration, and exchanges of cultural heritage resources residing in the Silk Roads region .

The main objectives of the DSRIF are:

(a) To undertake strategic planning, resource mobilization and management of a DSRIF network to be set up in partnership with universities, cultural heritage centers, UNESCO and institutions created within the framework of the former UNESCO Silk Roads project, and training institutions and IT centers established and reinforced or associated by UNESCO and NII in Silk Roads countries and nearby regions.

(b) To conduct scientific studies of Digital Silk Roads cultural heritage and cultural diversity led by an international joint team under the co-ordination of UNES$\mathrm{CO}$ and NII, taking into account historical, geographical, religious, and multilingual dimensions including the former Silk Roads projects such as Caravanserais in Central Asia.

(c) To carry out activities in launching, implementing and managing a variety of projects in key areas of dig- ital technology in the framework of the Digital Silk Roads project.

(d) To offer scholars, researchers, investigators, and other users of cultural and natural heritage resources currently available, and stimulate the sharing of these resources for academic and educational purposes.

(e) To establish centers or academies of excellence for cultural heritage restoration and archiving in the Silk Roads region.

Co-Executive Directors responsible for the DSRIF are Dr. Y. N. Kim (UNESCO) and Prof. Kinji Ono (NII).

\subsection{Major Achievements of the DSR Project}

Major achievements made so far can be summarized as follows:

1) Tokyo Symposium for Digital Silk Roads

"Tokyo Symposium for Digital Silk Roads" was held between December 11th and 13th, 2001. A public audience of 330 attended open lectures and more than 100 scholars and experts on information technology and cultural sciences from Japan and abroad gathered to discuss how to preserve and restore Silk Road heritage as well as how to make it available worldwide as a significant resource. The discussion culminated in the adoption of the "Tokyo Declaration on the Digital Silk Roads", which centered on the creation of a new approach linking cultural studies and information technology. 
A proceedings incorporating not only the presented papers but also poster sessions and exhibitions was published after the Symposium. [1]

\section{2) Nara Symposium for Digital Silk Roads}

Two years after the Tokyo symposium, a Digital Silk Roads symposium was held in the city of Nara, which at on point was considered Japan's gateway to foreign cultures.

A number of excellent invited presentations were made on the current status of research for Digital Silk Roads and the fusion of cultural studies and digital
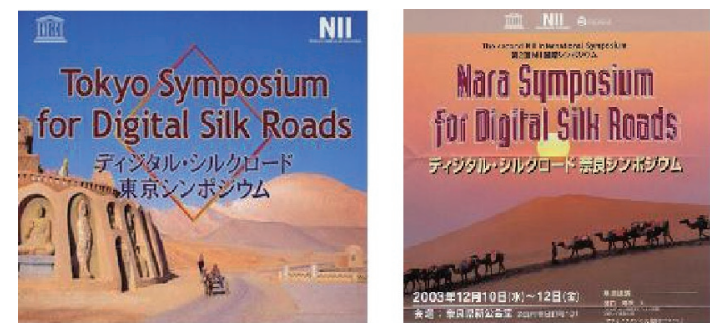

Fig. 2-4 Posters for the symposia
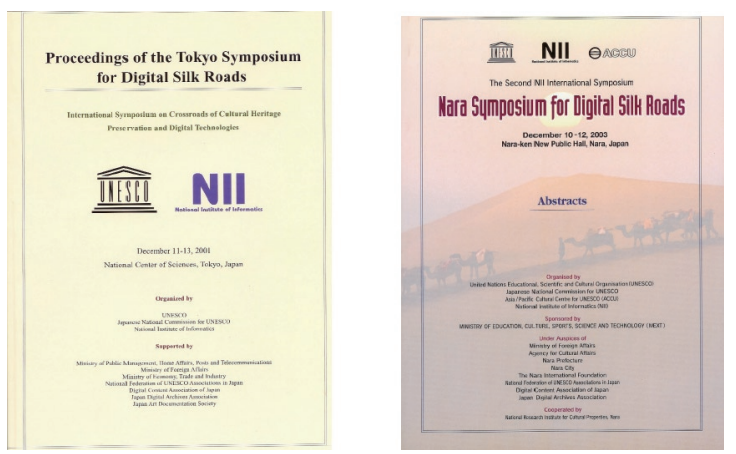

Fig. 2-5 Symposia proceedings

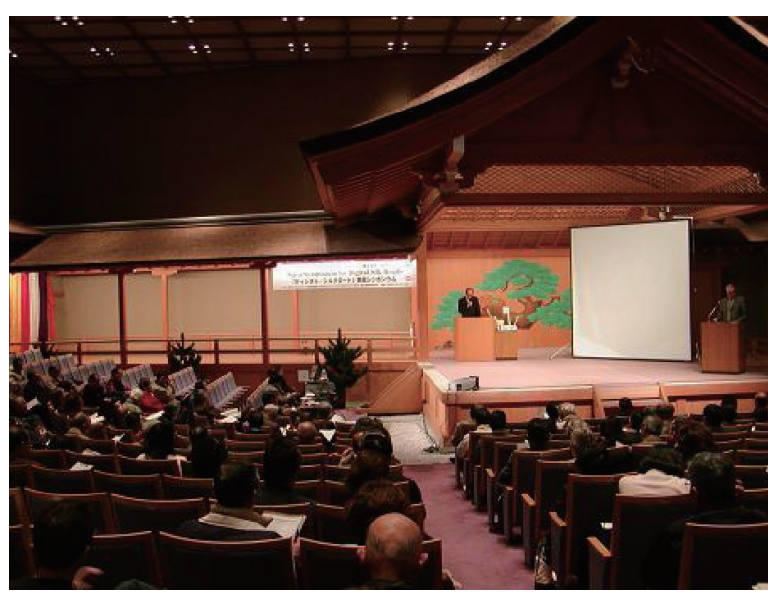

Fig. 2-6 A session at the Nara Symposium technology. A session to formulate future UNESCO strategy for promoting the DSR project was organized.

The session was followed by an awards ceremony at which DSR prize were awarded to the top three presentations. In addition, a study tour to some UNESCO World Heritage sites in Nara was offered after the ceremony.

The average attendance of the open sessions was some 240, and that of the expert sessions was around 150. About 50 scholars and experts took part from overseas, including many from nations along the Silk Road .

This symposium demonstrated the significant progress that had taken place after the Tokyo Symposium, and explored the new themes such as GIS and the Maritime Silk Road. [2]

Figure 2-4 shows the posters for the symposia. Figure 2-5 shows the cover sheets of the proceedings. Figure 2-6 shows the scene from a session at the Nara Symposium.

3) Digital archiving of rare books of the Toyo Bunko

Digital archiving of various historical documents, including rare books in the possession of the Toyo Bunko, an internationally renowned Asian studies library, was carried out. The main contents of this archive forms the "Image and Manuscript Database". Among the library's reputed collections of historical importance, one of the most famous is the "Morrison Library," which consists of 24,000 books about China and Asia written in various European languages. [11] [14][20][21][22]

4) The prototype Bamiyan Virtual Museum

After the Afghanistan war, a number of programs to support the country's recovery were launched.

The Digital Silk Roads project supported these programs.

Afghanistan's Bamiyan Buddhist ruins have been reproduced virtually as they were before their destruction under Taliban rule, using Hitacji's DIS(Digital Image System).[10] The prototype was created using the photos taken some 30 years ago in and around the Bamiyan ruins. The virtual museum was press released and opened to the media in April 2003. [19]

5) Reproducing the Bamiyan Buddhist Ruins on Video

The Bamiyan Buddhist ruins have been re-created on a high-definition digital video. One-hundred fifty photos, chosen out of a total of one thousand taken by Mr Takashi Echizen 25 years ago, were digitized with a high-definition scanner. To serve as the bases for the digital restoration, the video is unique in that, rather than employing traditional CG or virtual reality tech- 
nologies, it was created based on digitized $35-\mathrm{mm}$ photos with actual images of the ruins before their destruction.

\section{6) ASPICO Portal}

The "Advanced Scientific Portal for International Cooperation for Digital Silk Roads" (ASPICO-DSR) was developed by NII in cooperation with UNESCO.[15] This portal allows participants to create and store metadata through their personal workspaces. In addition, it provides a cooperation environment to discuss resources before releasing them into public arenas and to build multilingual textual contents. Thus, researchers can access high quality information without physical or social constraints. A new version of ASPICO which capable of performing ontology-based Metadata Management is currently under development.

7) The JSPS Asian Science Seminar (JASS'04)

The JSPS Asian Science Seminar (JASS'04) on Advanced Digital Technology-Assisted Cultural Archive and Preservation Along the Maritime Silk Roads was held in July 2004 at NII under the umbrella of DSRIF. The Seminar included 10 days of advanced training for young researchers in various fields in research methodologies related to the Maritime Silk Roads. The Seminar informed the participants of current practices on cultural resource management, including digital archiving, preservation and metadata management.

8) Southeast Asian Interactive Atlas 500-1500 A.D.

These study aims to develop a dynamic form of his- torical inquiry: visualizing cultural and ecological information across time and space on a digital map interface. Data on the natural and cultural history of Southeast Asia, linked to location, suggests relationships among cultures, societies, and the natural environment.

The project started in 2002 as an External Joint Research Project at NII with members of ECAI Southeast of the University of California, Berkeley who sought to share their data with other scholars. Kyoto University's Center for Southeast Asian Studies, in order to strengthen the joint information platform, has been digitizing its own holdings of maps, artifacts, photographs etc., and uploading maps and charts of Vietnam, Laos, and Cambodia. The Archaeological Computing Laboratory at the University of Sydney, which developed TimeMap, has constructed a database of the history of the ancient Khmer Empire that can generate an animation to spatially express the empire's expansion and decline. Figure 2-7 shows the ancient Khmer Empire's expansion and decline. The project will be linked to the work of Digital Silk Road, contributing to a larger understanding of the dynamics of trade and exchange not only in Southeast Asia, but also throughout the Eurasian continent.[21]

9) The National Cultural Heritage Online System

This project has been promoted by the Agency for Cultural Affairs, MEXT, to create a single Web portal tying together most major museums in Japan. The most advanced feature of the system is a prototype information system that provides easy and effective access to the digital repository on cultural heritage in Ja-

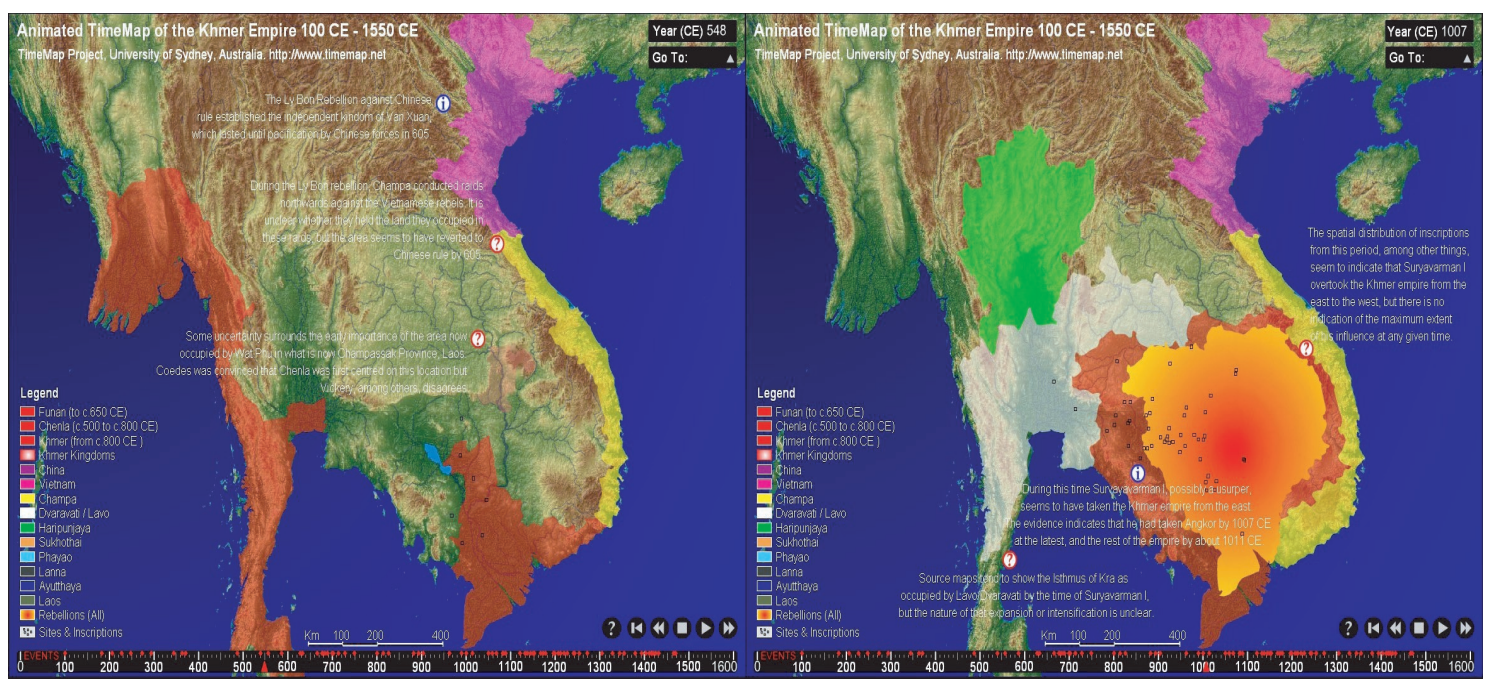

A.D. 548

A.D.1007

Fig. 2-7 The ancient Khmer Empire`s expansion and decline 


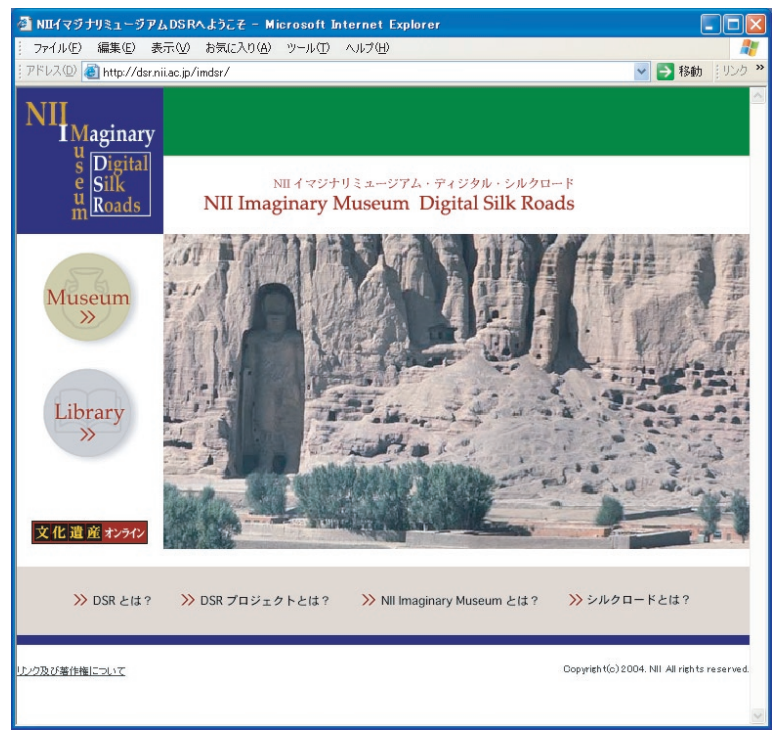

Fig. 2-8 Home Page of NII Imaginary Museum

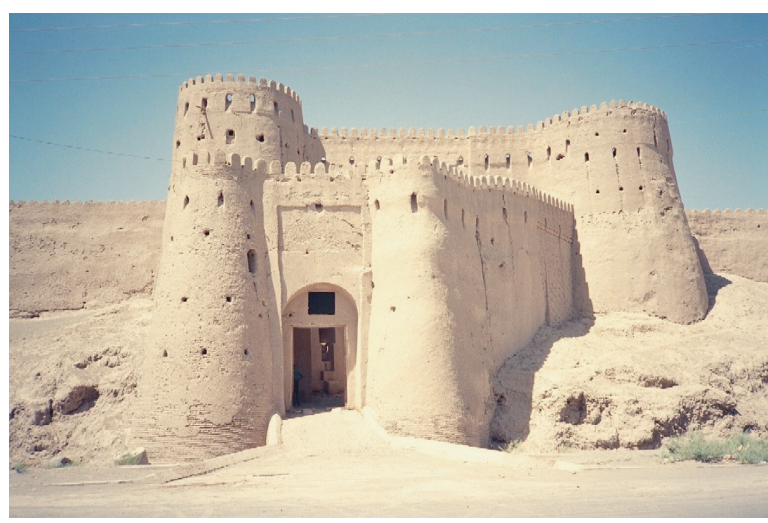

Photo

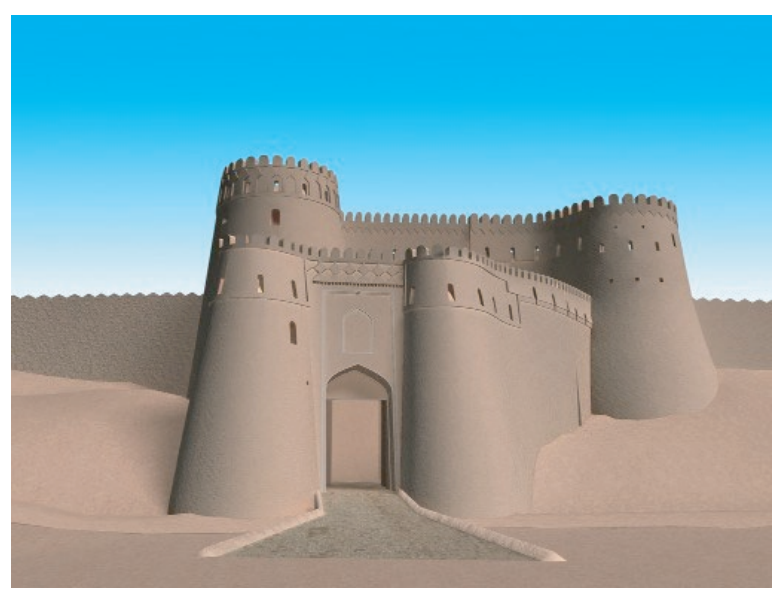

3D Model

Fig. 2-9 3D Model of the Entrance of Bam pan.[18] The type of virtual museum envisioned for Digital Silk Roads, the "NII Image Museum" (Figure $2-8$ ), is incorporated in this system.

10) Web Portal and 3D-VR restoration of the Citadel of Bam

In order to preserve the memories of the monument of Bam destroyed by an earthquake on December 26th 2004, a home page consisting of a collection of photographs and videos donated from various organizations and individuals was set up on the Web.

NII, in cooperation with ICHTO (Iranian Cultural Heritage and Tourism Organization), started a 3D reconstruction of the Citadel of Bam, inviting other organizations to collaborate and coordinating the project.

A 3D model of the entrance of the Citadel of Bam was created in cooperation with Dr. Kawai of Waseda University, GITI.

Figure 2-9 shows the photo before the earthquake and the 3D model of the entrance of the Citadel of Bam.

11) Multilingual and lexical terminology for caravanserais

Caravanserais are buildings which were constructed to shelter the men, goods and animals of caravans.

In order to establish an inventory of caravanserais, a multilingual terminology for caravanserais and a design for a lexical description model for historical architecture terminology are being investigated.

Research is currently focusing on proper ontological model for visualizing and presenting the special data of caravanserais.

\subsection{Future perspectives}

One main feature of the project is to provide a global platform for collaboration of the world's scholars through a network based on the GMR concept. As a common platform to serve this purpose, a multimedia open-source software centering on ASPICO-DSR is available not only to specialists but also to the public.

The database, which interacts with existing systems, features an intelligent, user-friendly interface that focuses on multi-language processing and metadata.

Major technical goals are as follows:

1) to collect historical and cultural heritage resources

Currently the most important task is to collect the historical and cultural materials in Silk Road countries, digitize them, and store them in a database so as to enable the researchers involved to input any available related data, filling in missing information and further improving the restored images in the database. The scheme doesn't only aim at ordinary visual repro- 
duction; it intends to realize $3 \mathrm{D}-\mathrm{VR}$ restoration in the future, taking into account the spatial configuration within which artifacts are located.

2) to find a new automatic process for the creation of metadata, and annotation of such digital contents so as to improve access to, retrieval of, and interaction with multimedia cultural content[3][4][6]

For this purpose we are constructing ontology for cultural heritage domains, focusing on the caravanserais of the Silk Roads in collaboration with domain experts who have rich knowledge in the field. Ontology is very important for data exchange among DSR researchers, museums, digital libraries, and digital archives. We are currently developing a domain ontology covering concepts relevant to cultural heritage information.[12][13]

3) to ensure interoperability between distributed multimedia repositories

Existing multimedia information systems such as digital museums and digital libraries have mostly been built in isolation, using incompatible methods. In order to solve these problems, DSR puts emphasis on finding architectures that provide a common framework for multimedia objects combination and exploitation in distributed multimedia cultural heritage environments. Gateway function interconnection between different resources is also under development.

4) to develop suitable interfaces for the digital repository

The DSR seeks to address the question of how various devices can handle the presentation of multimedia information and be adapted to fit users' preferences, languages, capabilities, cultures and other characteristics.A multilingual interface in particular, is the key issue for inter-cultural collaborative studies.

\section{5) to enhance the DSR portal to benefit users}

The Web portal of DSR aims at facilitating international joint research by making important archive materials available online, along with other related information. The Virtual Laboratory for Digital Silk Roads will be organized using the DSR portal.

\section{Toyo Bunko Rare Books Digital Archive \\ 3.1 Overview}

In this part of the DSR Project, we have created a digital archive of some of the rare books on silk road studies held by the Toyo Bunko.

Toyo Bunko ("The Oriental Library") is a library and research institute specializing in Asian studies. It was founded by Hisaya Iwasaki (1865-1955), the third president of the Mitsubishi Enterprise Group who, in 1917, purchased the whole private library of George Ernest Morrison, a rare collection of 24,000 books about China and other Asian countries in European languages. Morrison was a long-time resident of China and wrote for the London Times, and later served as political advisor to the Office of the President of the Republic of China. Iwasaki added other books, in European, Japanese and other Asian languages, to the collection and established the Toyo Bunko in 1924. Currently with 880,000 books, the majority of which in European languages and many in various Asiatic languages, it is one of the five leading Asian studies libraries in the world and the largest such one in Japan.

We based development of the digital archive on the following principles:

1) Meticulous and high-precision digitization of the whole of the material

In digitizing precious books, we have used a book cradle $^{1}$ to minimize the impact of opening the pages for photographing. Cover-to-cover photographs of the books were taken in high-resolution (over 4000x4000) , high-fidelity cameras for long-term preservation and for further digital processing. With such precise images, most books can be seen in greater detail than just looking at the book with the naked eye and can be used as a material for detailed research, such as comparative studies of different versions of the text. Such images can also be used for migration to other platforms, should such became necessary with the passage of time, and shall be appropriate for future use as a higher grade media output.

\section{2) Wide and rapid usage of the web pages}

We have made the material freely accessible through the web, from anyone in the world, as quickly as possible. Some of the materials are very rare, possibly the only copy in the world, and although some others are classical textbooks, not everyone can access them for study, especially in places such as Silk Road regions. Web pages were initially made with minimal manual intervention by using IT methods such as OCR and automatic translation, although those processes are known to leave errors. The resultant web pages (900x900 color, and 2000x2000 gray) were made public as soon as possible, so that worldwide users can make use of them even while the data is being cleaned and further improved upon. Precious human resources such as Silk Road researchers were utilized for organizing thesaurus and for checking translation of important parts of data. Correcting OCR errors in the

\footnotetext{
' http://www.humi.keio.ac.jp/docs/digital/html/bookcradle/ bookcradlemain.html
} 
Table 3-1. Materials digitized in FY2002

\begin{tabular}{|c|c|c|c|}
\hline Title & Author & Notes & $\begin{array}{l}\text { Total } \\
\text { Image }\end{array}$ \\
\hline $\begin{array}{l}\text { Die buddhistische Sp_tantike in } \\
\text { Mittelasien } \\
\text { Vol.1 : Die Plastik } \\
\text { Vol.2 : Die manichaeischen Miniaturen } \\
\text { Vol.3 : Die Wandmalereien } \\
\text { Vol.4 : Atlas zu den Wandmalereien } \\
\text { Vol.5 : Neue Bildwerke } \\
\text { Vol.6 : Neue Bildwerke II } \\
\text { Vol.7 : Neue Bildwerke III }\end{array}$ & $\begin{array}{l}\text { Le Coq, } \\
\text { Albert von }\end{array}$ & $\begin{array}{l}\text { Featuring artifacts collected } \\
\text { during four expeditions by Le Coq. } \\
\text { Vol.1 : Sculptures } \\
\text { Vol.2 : Manichaean Miniatures } \\
\text { Vol.3 : Mainly introducing murals } \\
\text { Vol.4 : Mural designs } \\
\text { Vol.5 : New pictures } \\
\text { Vol.6 : New pictures II } \\
\text { Vol.7 : New pictures III }\end{array}$ & 681 \\
\hline Ein Tagebuch in Bildern & $\begin{array}{l}\text { Mumm, Alfons, } \\
\text { Freiherr von Sch- } \\
\text { warzenstein }\end{array}$ & $\begin{array}{l}\text { A collection of photographs in } \\
\text { China }\end{array}$ & 277 \\
\hline $\begin{array}{l}\text { Results of a scientific mission to India } \\
\text { and high Asia } \\
\text { Atlas Part I IV }\end{array}$ & $\begin{array}{l}\text { Schlagintweit- } \\
\text { Sakünlünski, } \\
\text { Hermann von }\end{array}$ & $\begin{array}{l}\text { Reporting the results of their expedi- } \\
\text { tion. Those featuring sketches and } \\
\text { drawings of Kharakhorum and Kunlun } \\
\text { Mt. are extremely rare. }\end{array}$ & 57 \\
\hline Views of China & $\begin{array}{l}\text { Morrison, } \\
\text { George } \\
\text { Ernest (?) }\end{array}$ & A collections of photographs in China & 53 \\
\hline $\begin{array}{l}\text { Storia della Spedizione scientifica itali- } \\
\text { ana nel Himàlaia Caracorùm e Turches- } \\
\text { tan cinese }\end{array}$ & $\begin{array}{l}\text { Filippi, } \\
\text { Filippo de }\end{array}$ & $\begin{array}{l}\text { History of an Italian science expedition } \\
\text { to the Himalayas, Kharakhorum and } \\
\text { Chinese Turkistan. }\end{array}$ & 595 \\
\hline
\end{tabular}

body of text will be done as time and resources are available. It was hoped that users will cooperate by reporting errors etc.

\section{3) Multilingual access,}

As we expect the material to be used in many parts of the world, the web site page titles and messages are at least bilingual in English and Japanese. Also, the table of content and figure captions were extracted and translated (if they are not originally) into English and Japanese, and made into separate web pages. All the words in the original text were digitized by using a multilingual OCR software, and combined with the translated indexes, made searchable by GETA ${ }^{2}$. However, by using a multilingual thesaurus accumulated by MASS (Multilingual-term Accumulation Support System) in this project, which will be described in Section 3.3, important specialized terms such as place names, persons' names and names of cultural artifacts are searchable in several (up to eight) languages.

There are 35 books (about 9,000 pages) on our web-

\footnotetext{
http://geta.ex.nii.ac.jp/

${ }^{3}$ http://dsr.nii.ac.jp/toyobunko/
}

site $^{3}$ now, as described in more detail in Section 3.2 In Section 3.3, the development of a multilingual thesaurus by using a software we have developed, MASS. In Section 3.4, the multilingual search capability in our web site realized by using the multilingual thesaurus will be described.

\subsection{The contents and characteristics of the material}

In this project, we have chosen materials in several European languages (French, Italian, German, Swedish and English) describing $19^{\text {th }}$ Century and early $20^{\text {th }}$ Century European expeditions, which are important for the study of the Silk Roads, and some ancient Chinese historical texts, that describe the Central Asian regions. All materials are without copyright restrictions and all pages, cover to cover, are available to be accessed as images. The following tables 3-1 to 3-3 list materials digitized and put on the web in this project between fiscal year 2002 and 2004.

Many of these materials are authored by well-known explorers from different European countries. They write them from different points of view on their own and others' expeditions and give various descriptions of Central Asia's societies, cultures and heritages. What is common to them are their desire to describe 
Table 3-2. Materials digitized in FY2003

\begin{tabular}{|c|c|c|c|}
\hline Title & Author & Notes & $\begin{array}{l}\text { Total } \\
\text { Image }\end{array}$ \\
\hline $\begin{array}{l}\text { Cathay and the way thither : being a } \\
\text { collection of medieval notices of China } \\
\text { Vol.1,2 }\end{array}$ & Yule, Henry, Sir & $\begin{array}{l}\text { His most important work for Silk Road } \\
\text { study. } \\
\text { Vol.1 : Text and maps } \\
\text { Vol.2: Text, map and index }\end{array}$ & 990 \\
\hline $\begin{array}{l}\text { Explorations in Turkestan : with an ac- } \\
\text { count of the basin of Eastern Persia and } \\
\text { Sistan. Expedition of } 1903\end{array}$ & $\begin{array}{l}\text { Pumpelly, Ra- } \\
\text { phael }\end{array}$ & $\begin{array}{l}\text { A report of the } 1903 \text { excavation of the } \\
\text { Annau and Merv ruins. }\end{array}$ & 362 \\
\hline $\begin{array}{l}\text { Explorations in Turkestan, expedition } \\
\text { of } 1904 \text { : prehistoric civilizations of } \\
\text { Anau, origins, growth, and influence of } \\
\text { environment } \\
\text { Vol.2 }\end{array}$ & $\begin{array}{l}\text { Pumpelly, Ra- } \\
\text { phael }\end{array}$ & $\begin{array}{l}\text { A report of the } 1904 \text { expedition. Physi- } \\
\text { ography of Central-Asian deserts and } \\
\text { oases. }\end{array}$ & 327 \\
\hline 史記第百二十三巻大宛列傳第六十三 & Si ma qian & $\begin{array}{l}\text { No. 63, Vol. 123, "Account of Ferghana", } \\
\text { Records of the Grand Historian of Chi- } \\
\text { na }\end{array}$ & 42 \\
\hline 前漢書巻九十四下洶奴傳第六十四下 & Ban-gu & $\begin{array}{l}\text { No. } 64 \text { bottom, Volume } 94 \text { bottom, } \\
\text { "Account of the Xiongnu", Historical } \\
\text { Records of the Former Han Dynasty }\end{array}$ & 66 \\
\hline $\begin{array}{l}\text { 前漢書巻九十五西南夷兩粤朝鮮傳第 } \\
\text { 六十五 }\end{array}$ & Ban-gu & $\begin{array}{l}\text { No. } 65 \text { bottom, Volume 95, "Biography } \\
\text { of Yunnan, Nanyue, Dongyue and Ko- } \\
\text { rea", Historical Records of the Former } \\
\text { Han Dynastydeath. }\end{array}$ & 52 \\
\hline 前漢書巻九十六上西域傳第六十六上 & Ban-gu & $\begin{array}{l}\text { No. } 66 \text { top, Volume } 96 \text { top, "Geo- } \\
\text { graphical Accounts of the Western } \\
\text { Area", Historical Records of the For- } \\
\text { mer Han Dynasty }\end{array}$ & 44 \\
\hline 前漢書巻九十六下西域傳第六十六下 & Ban-gu & $\begin{array}{l}\text { No. } 66 \text { bottom, Volume } 96 \text { bottom, } \\
\text { "Geographical Accounts of the Western } \\
\text { Area", Historical Records of the For- } \\
\text { mer Han Dynasty }\end{array}$ & 52 \\
\hline Ot Kiakhty na istoki Zheltoi Rieki & $\begin{array}{l}\text { Przheval'skii, } \\
\text { Nikolai Mikhailo- } \\
\text { vich }\end{array}$ & $\begin{array}{l}\text { "From Kyakhta to the source of the } \\
\text { Yellow River" }\end{array}$ & 594 \\
\hline $\begin{array}{l}\text { Mongoliia i Kam : trudy ekspeditsii Im- } \\
\text { peratorskago Russkago geografiches- } \\
\text { kago Obshchestva, sovershennoi v } \\
\text { 1899-1901.gg } \\
\text { Vol.1 5 }\end{array}$ & $\begin{array}{l}\text { Kozlov, Petr } \\
\text { Kuzimich }\end{array}$ & $\begin{array}{l}\text { "Mongolia and Kham, Achievements of } \\
\text { the Geographical Association Expedi- } \\
\text { tions in Imperial Russia v1899-1901.gg" } \\
\text { Vol.1 3 : Text, photos and maps } \\
\text { Vol.4 : Maps } \\
\text { Vol.5 : Text, colored pictures and map }\end{array}$ & 1435 \\
\hline
\end{tabular}

and publish what they found and saw in great detail, for scholarship's sake. Many things that they described have since lost, due to war (both in Asia and in Europe,) vandalism, greed or just by the force of nature, and for some, these pages may be their only record left. The contents of this digital archive, therefore, is a valuable source of information for the study of not only archaeology or history, but also folklore, art history, geography, religion, politics, linguistics and other fields. 
Table 3-3. Materials digitized in FY2004

\begin{tabular}{|c|c|c|c|}
\hline Title & Author & Notes & $\begin{array}{l}\text { Total } \\
\text { Image }\end{array}$ \\
\hline $\begin{array}{l}\text { Ancient Khotan : detailed report of ar- } \\
\text { chaeological explorations in Chinese } \\
\text { Turkistan } \\
\text { Vol.1,2 }\end{array}$ & $\begin{array}{l}\text { Stein, Mark Au- } \\
\text { rel }\end{array}$ & $\begin{array}{l}\text { The academic report of his first explora- } \\
\text { tion in Central Asia. } \\
\text { Vol.1 : Text, illustrations and appen- } \\
\text { dices } \\
\text { Vol. } 2 \text { : Plates of photographs, plans, an- } \\
\text { tiques and Mss., with a map of the terri- } \\
\text { tory of Khotan from original surveys }\end{array}$ & 826 \\
\hline $\begin{array}{l}\text { Serindia : detailed report of explora- } \\
\text { tions in Central Asia and western most } \\
\text { China } \\
\text { Vol.1 5 }\end{array}$ & $\begin{array}{l}\text { Stein, Mark Au- } \\
\text { rel }\end{array}$ & $\begin{array}{l}\text { The academic report of his second ex- } \\
\text { ploration in Central Asia. } \\
\text { Vol. } 1 \sim 3: \text { Text } \\
\text { Vol. } 4: \text { Plates } \\
\text { Vol.5 : Maps }\end{array}$ & 2145 \\
\hline Den vandrande sjön & $\begin{array}{l}\text { Hedin, Sven An- } \\
\text { ders }\end{array}$ & $\begin{array}{l}\text { "The Wandering Lake" } \\
\text { A report of his last exploration in Cen- } \\
\text { tral Asia. }\end{array}$ & 464 \\
\hline
\end{tabular}

\subsection{Multilingual-term Accumulation Support System (MASS)} and the multilingual thesaurus

During the project, necessity of a tool for collecting specialized technical terms, such as names of people and places, religious terms and terms in archeology and art history, was felt. It needed to be accessible over the internet from all over the world (some of our collaborators are in China and Austria,) and it had to be usable as a tool for cooperation and standardization among translators, proofreaders and those who develop summary and index web pages. The user had to be able to search and update the data base independently, and the result of the update should be reflected immediately. It needed to have a simple enough user interface usable for computer novices, and most important, it had to be usable in any language within the Unicode. As there are many variant spellings of the same term, especially in the current field in which terms for several European languages are transliterated Asian words, a fuzzy (non-exact) matching which can find those variations is essential.

We looked for it but found none, at least as an opensource software, so developed it. The software, MASS (Multilingual-term Accumulation Support System) consists of a server, which uses a relational database system (in our case MySQL) to provide a web service, and client package, whose user interface looks like Microsoft Excel(the user needs to have it installed) but actually is not Excel but a front end for the database.

The user interface is shown in Fig. 3-1 to Fig. 3-3. As the program starts, it is in the search mode (Fig. 3-1). The user enters a term (word or phrase) and searches if there is a close match (the same spelling except for upper/lower case difference and presence/ absence of diacritical marks.)

In Fig.3-2, the system reports no close match, so the user chooses "Expand Search" from the mouse rightclick menu.

Fig. 3-3 shows the result of the expanded search.

The first record shows the intended match, "Kizil" or "Qyzil" instead of "Kizyl" but is sufficiently close. In the third record, "Jizya," the substring "izy" matched, with edit distance 2 .

In the second record, the Soundex algorithm detected similarity between "Kizyl" and "gao ju li", judging perhaps that $\mathrm{K}$ and $\mathrm{g}$ are sufficiently close, vowels $\mathrm{i}$ and ao are can be safely ignored, and consonants $\mathrm{z}$ and $\mathrm{j}$ could be the same sound.

At this stage, if "Kizyl" were a genuine word found in the text, the user could add it to the database. (Actually it is a ficticious entry used for the explanation.)

Another feature of MASS is automatic romanization (transliteration into lower-case alphabet) by using a Perl library program. For latin alphabet expressions, it takes away diacritical marks (accent symbols) and converts upper-case characters to lower-case. In Chinese, it generates pinyin. In non-latin alphabets such as Hangul, Kiril and Thai characters, it transliterates using one of several standard methods. The procedure is not error-free, but in most cases it is reasonably correct. For Japanese Kanji, it still tries to generate pinyin, so it is turned off in MASS. Actually, in MASS the feature can be turned on or off for each language.

The system uses two fuzzy-match algorithms, edit 


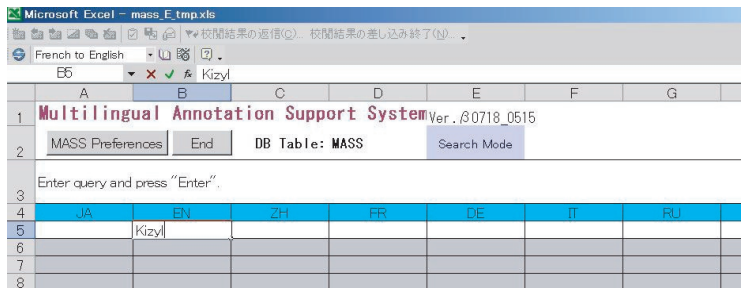

Fig. 3-1 Start of the MASS client

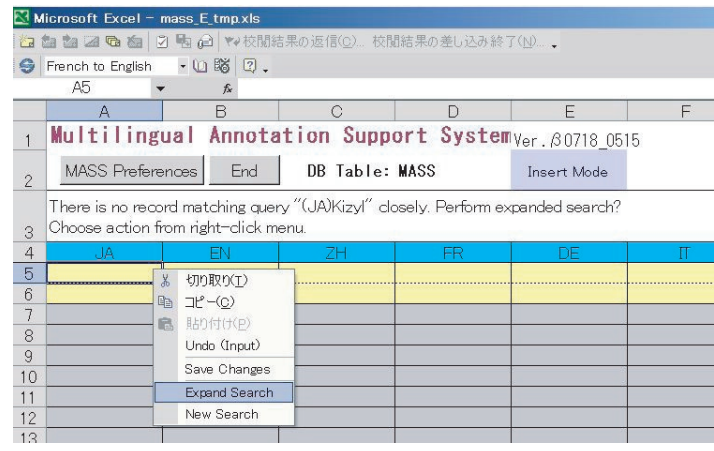

Fig. 3.2 Choosing "Expand Search"

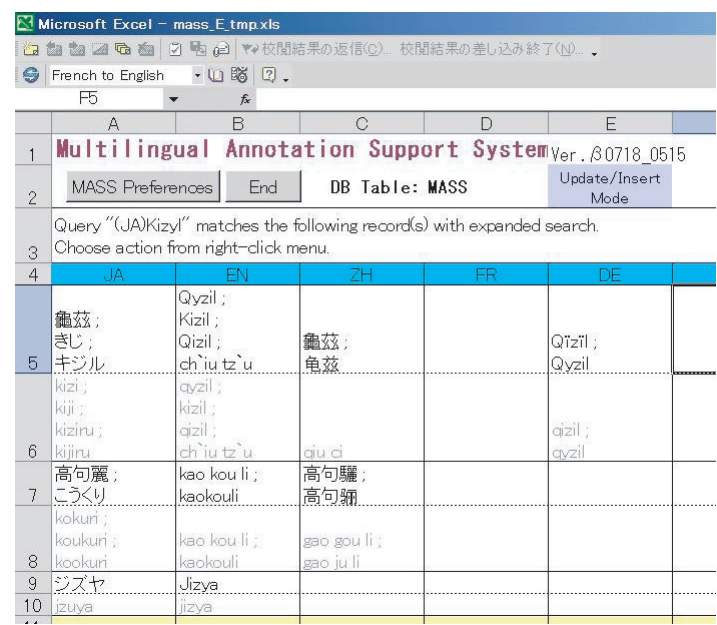

Fig. 3-3 Result of the fuzzy matching

distance and soundex, for finding technical terms with similar but variant spellings. There are several parameters which can be set to optimize the search. They are, the maximum edit distance, the percentage of the edit distance within the length of the shorter term to be compared, and whether the soundex is added to widen the search or not. Different values of those parameters can be set for different language.

MASS has helped in standardizing translations and terminology within the project. It was also used for international workshop related to DSR, and was highly popular among the Asian participants. At the present

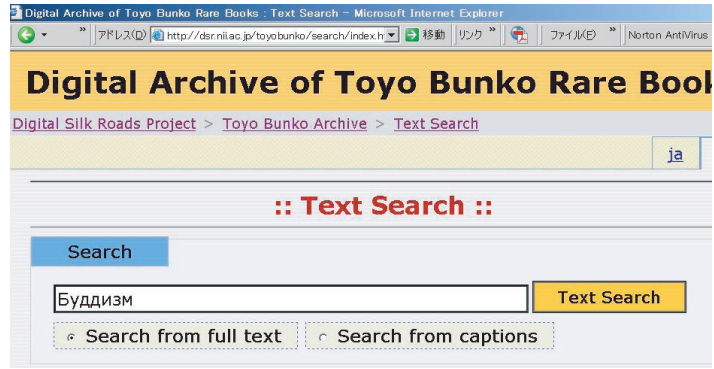

Fig. 3-4 Searching in Russian for

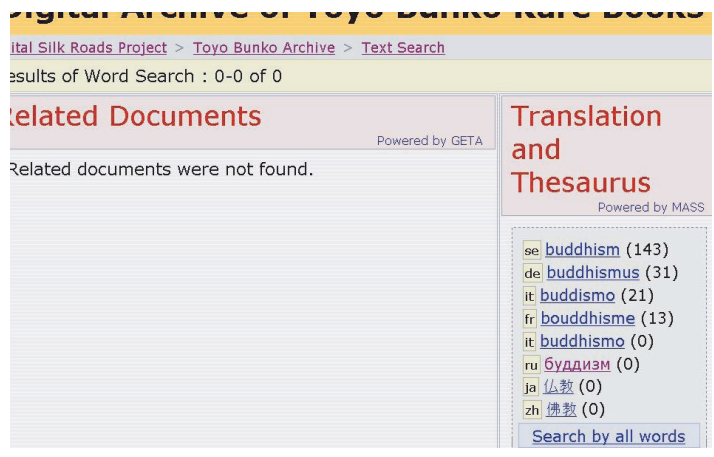

Fig. 3-5 Multilingual search result

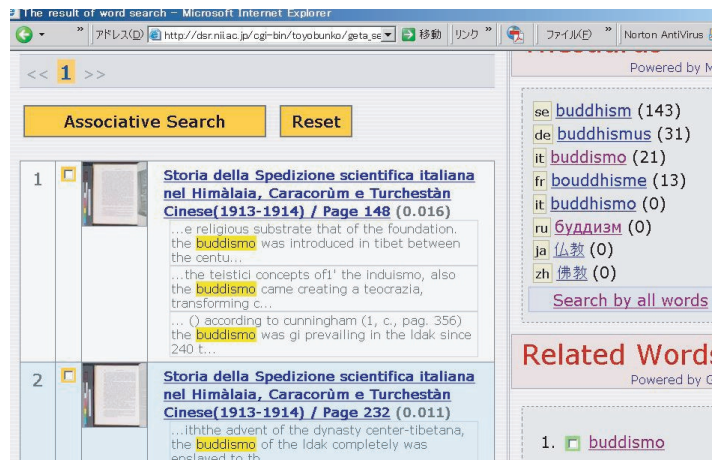

Fig. 3-6 Result in Italian

time it is only on an internal server (separate from the main Web server), but the system will be made available as an open-source software in the near future.

3.4 Multilingual text search by using the multilingual thesaurus

MASS can be used in several ways, including organizing data for hierarchical thesaurus. However, we will describe usage of its product for multilingual text search in the main web site.

Say, for example, a user in Russia wanted to search the database for "Buddhism." As shown in Fig. 3-4, 
The user can use Russian in Kiril characters for the text search.

The word does not appear in the current database, but as shown in Fig. 3-5, there are 143 hits in English (buddhism), 31 in German (buddhismus), 21 in Italian (buddismo) and 13 in French (bouddhisme).

Fig. 3-6 shows the result of choosing the Italian hits. This demonstrates that, as long as the relevant words are in MASS, the full-text search can be done using any of the languages in the database, with results obtainable in the same or any other language contained therein .

The authors thank the team members who programmed the MASS system, loaded it with multilingual contents, and helped correct mistakes there.

\section{Prototype of the Bamiyan Virtual Museum \\ 4.1 The outline of the Bamiyan Virtual Museum}

The Silk Roads prospered as a trade route between East and West for many years, and much of the cultural and natural heritage from that period has survived. Unfortunately, however, much of that heritage has continued to suffer from natural degradation as well as destruction by human agency, and the situation has now reached near-crisis proportions. Faced with this situation, an international collaborative project known as "Digital Silk Roads" has been developed for the purposes of digitally preserving world heritage, to promoting cross-cultural and cross-disciplinary exchanges and to creating new intellectual assets utilizing the preserved data.

As a part of this project, we urgently need a system to archive cultural heritage, including fading remains and traditional performing arts, in a digital format. These data will be utilized for research, with the research results utilized for a wide variety of purposes within society.

As the project's first step, NII and Hitachi have jointly been developing a prototype virtual museum of the archeological remains of the Bamiyan Valley in

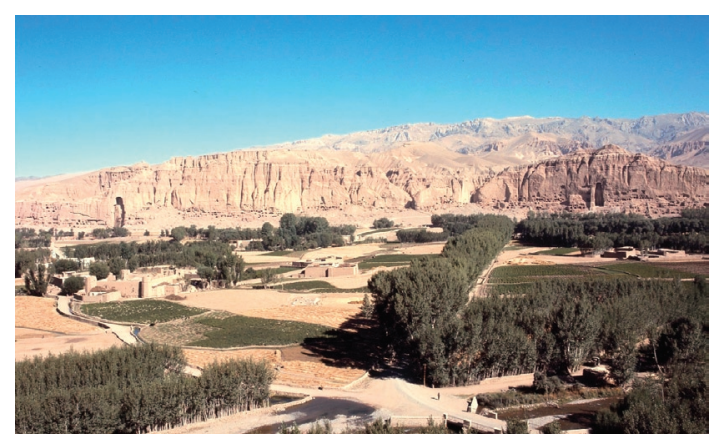

Fig. 4-1 Bamiyan Valley in Afghanistan
Afghanistan (hereinafter referred to as the "Bamiyan Virtual Museum"), a World Heritage site, which requires urgent conservation measures of conservation after having suffered further a great deal of damages recently, both at the hands of the Taliban and in the Afghan war.

The Bamiyan remains lie in a valley in the Hindu Kush Mountains , 2,500 meters above sea level. There are about 750 caves in the cliffs within the valley, cliffs which rise to a height of 150 meters above the floor of the valley and have a total width of 1,300 meters. The remains in these caves are extremely important archeological resources for understanding, what society was like, during the era in which Bamiyan prospered.

Strategically situated in a location central for travelers from all directions and in the middle of the famous Silk Roads, this religious center was a common meeting place for different cultures and ideologies since the ancient times, leading the inhabitants to have a unique worldview.

Today, the remains are in a very fragile state as a result of abandonment, military action and dynamite explosions. With this mind, we have employed our DIS technology to record the remains in order to decipher their significance.

The first step was to collect existing images of the site. Prof. Higuchi had taken photographs of Bamiyan before the former Soviet Army launched their attack against Afghanistan in 1979. These photos were digitized and stored in a database for effective use in academic and artistic researches.

We also undertook virtual reconstruction of the remains establishing a digital archive system, that efficiently searches, and exhibits the desired information.

This system runs on two proprietary engines, developed by Hitachi, one is a user-friendly, high-speed display engine that instantly shows desired images, and the other is a script language engine that flexibly copes with further expansions, and/or changes in func-

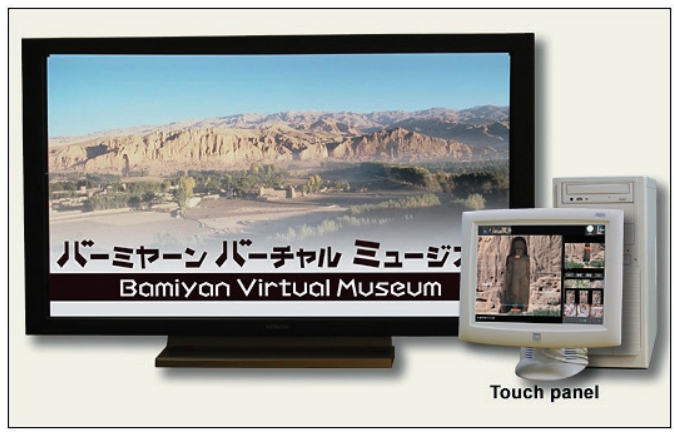

Fig. 4-2 Bamiyan Virtual Museum 


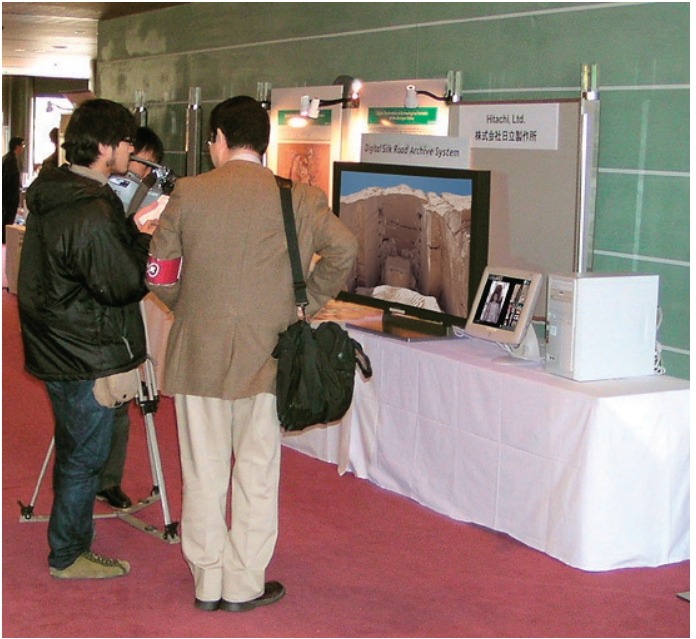

Fig. 4-3 Exhibition at the Nara Symposium for Digital Silk Roads

tion.

The engines are controlled by a touch panel, and show the selected images on a 50-inch high-definition plasma display.

Data retrieval starts with a panoramic view of the remains. Images resulting from a specific search can be magnified or compared with other images, without sacrificing speed.

One of the advantages of the system is its ease of operation, even for those unfamiliar with computers, and high-speed access to the searched data. You can navigate easily through the details of the Bamiyan remains simply by touching the maps and images displayed on the panel. The search results also include lists of research materials, such as mural paintings, interior structures, etc. categorized by cave. These imag-

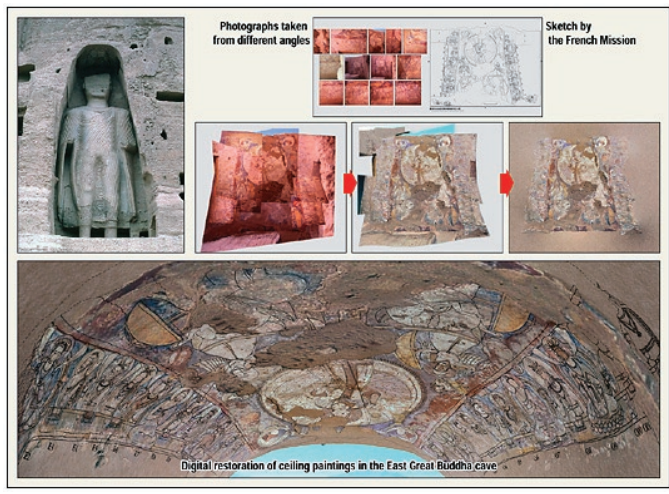

Fig. 4-4 Digital restoration

es may be further selected for a closer look on a large high-definition display.

Moreover, a range of display formats is available; any part of an image, can be magnified or compared or combined with others. Explanatory captions can be added.

The Bamiyan remains hold numerous important mural paintings; one on the ceiling of the East Great Buddha cave, in particular shows the integration of Buddhism with Indian, Persian, and Greek myth. We are working on a digital restoration of this mural using a proprietary process. The process started with photographs of the painting taken at several angles along with existing sketches done by the French Mission in the 1920s. DIS filters corrected for the difference in camera angles and color tones among the photos, as

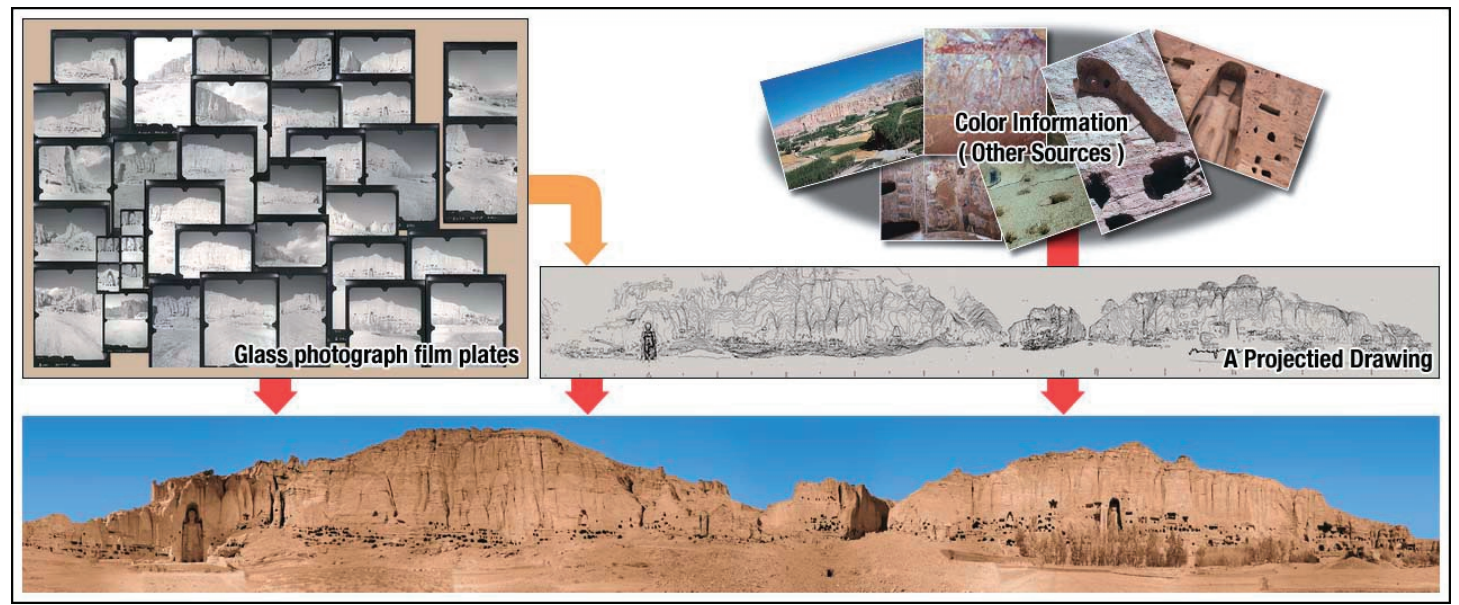

Fig. 4-5 The Complete View of the Bamiyan Remains 
well as correcting for distortions caused by the curve of the domed ceiling in order to fit the contour lines of the base sketch.

Missing sections were filled in using existing photographs and the related information from available sources .

The restored image has cleaned up the picture as a whole and refined details of the painting that were difficult to grasp from the individual photographs; the central figure is now believed to be the Indian sun god Surya or the Iranian god of light Mithra on a coach-infour .

Other figures seem to represent wind gods, winged guardian deities, kinnaras (creatures from Thai mythology) and two hamsa (geese). We aim to further collect and add more information in order to improve the quality of the restoration.

One of our immediate goals is to apply the digitally restored ceiling painting to a life-size reproduction on a ceramic board, and to realize a $3 \mathrm{D}$ reproduction that includes the ambience surrounding the cave. The ceramic-board recreation of the revived painting will last almost indefinitely, allowing us to exhibit it, for example at Kabul Museum and other locations, as a model of the remains.

The full-color panoramic view is another artifact of DIS, created from 30 black and white pictures that were originally taken for a geodesic survey, with color information extracted from other color photographs.

\subsection{DIS Technology}

- The basis of the Bamiyan Virtual Museum -

DIS technology, developed over 10 years by a Hitachi research team, is used in the Bamiyan Virtual Museum.

DIS broadens the scope of imaging technology, creating images of a fineness unimaginable with conventional techniques. It represents a significant new ap-

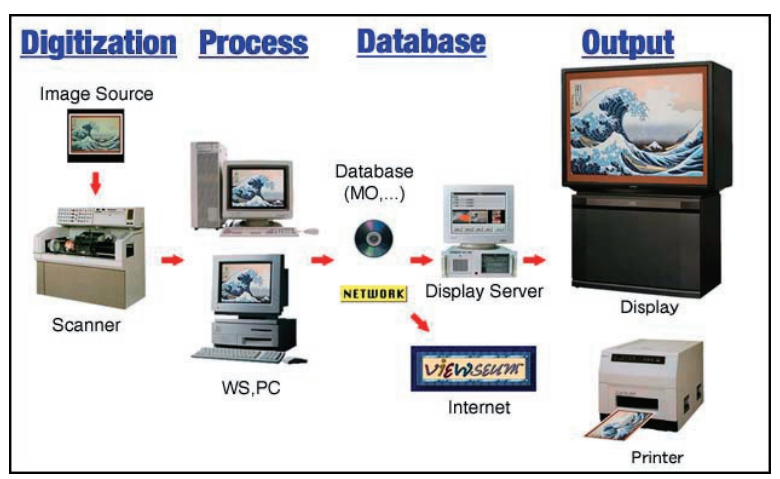

Fig. 4-6 DIS System Configuration proach towards the documentation, preservation and exhibition of valuable treasures owned by museums and libraries.

Our main focus in developing the DIS was to preserve the esthetic quality as well as the historical significance of cultural heritages materials, and to make them accessible to everyone around the world at any time. Figure 4-6 shows the configuration of the system in which all processes are conducted in digital format in order to maximize the value of information collected from the image sources.

The DIS process consists of four major steps: 1) digitization of image sources; 2) processing the artwork "as is" or enhancing it to allow researchers to test hypotheses while keeping the originals intact; 3) creation of a systematized database, including information regarding scientific analyses and the expertise of traditional artists, for effective application at later stages; and 4) output of the integrated information to an appropriate form or system. Prints are of such high quality that they will survive the test of time for the conceivable future.

DIS does more than merely create a digital reproduction of cultural properties. It conducts all the steps involved in digitization, image processing, database creation, and output in digital form; we utilize various types of scanners to first digitize the target objects. The most notable features of DIS technology are a set of software tools called DIS Filters, and technologies for their application such as the DIS Image Engine and DIS Printing.

One of the most distinctive proprietary software tools developed by Hitachi is a set of DIS Filters, which are used to manipulate the image in forms and colors of images.

DIS Filters, our revolutionary computation programs, allow us to process image files while keeping

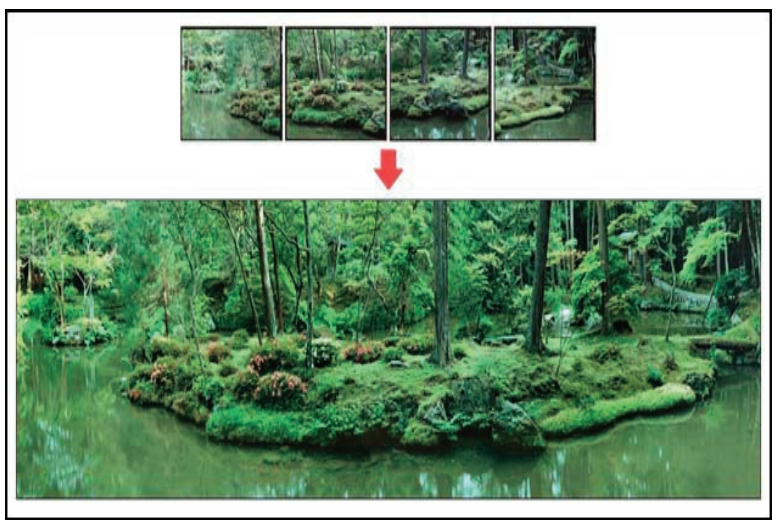

Fig. 4-7 Example of DIS Filters 
the quality of the images fully intact. They can extract valuable information from color, infrared, and $\mathrm{x}$-ray images, and merge them together so that they can be analyzed in scientific researches. Filters are of the following types:
De-Aging Filter - restores the colors of original works that have suffered discoloration and shade change over time.

Repairing Filter - counteracts damage such as stains, creases and scratches present in the original.

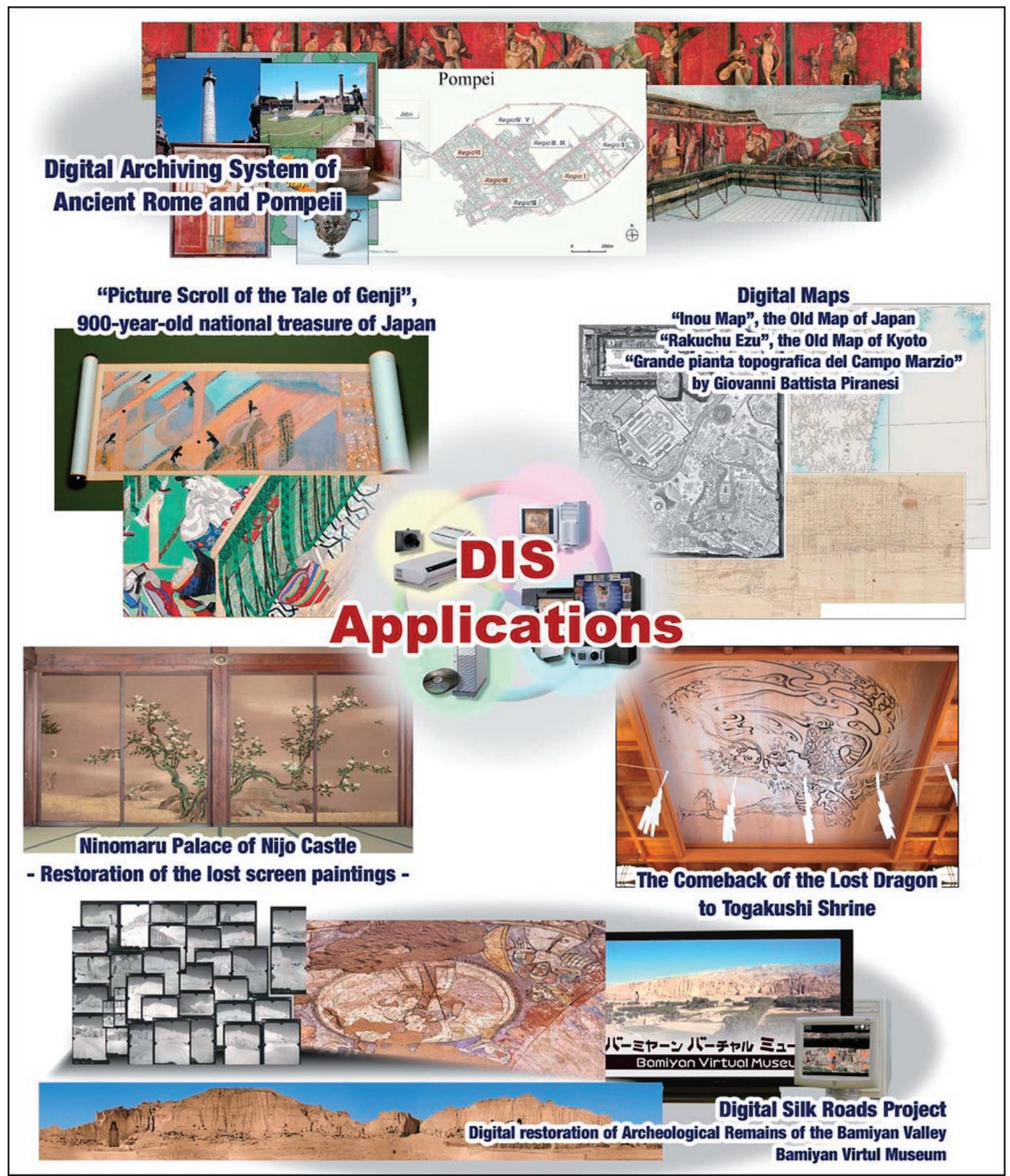

Fig. 4-8 DIS Applications 
Deformation and Switching Filter - modifies the images into correct desired forms; e.g. corrects any distortion of images caused by the lens at the time of shooting; and joins multiple images taken from different angles into a single seamless picture.

Color Morphing Filter - changes the color tones to suit the intended purpose; suitable for machine adjustment of color tones among multiple images.

Re-Sizing Filter - displays magnified images in high quality.

Figure 4-7 shows an example of the capabilities of the Filters. The original materials are photographs of Moss Garden at Saiho-ji Temple in Kyoto taken from 4 angles, which unavoidably vary in color tones, and have distortions caused by the lens. Such deviations among the images were corrected and the images were synthesized into one photograph. The DIS is capable of creating a truly realistic image, which is not possible to view in the real world due to limits imposed by the angle of the human eye and the obstruction created by trees at the desired showing site.

The DIS Image Engine maximizes the quality of image and text data without sacrificing speed. This engine provides digital archive systems with a highspeed search function, visual programs, and presentation systems with high-quality images and synchronized narrations in order to enhance user-friendliness. They can all be shown on a variety of display sizes, from laptop PC screens to display panels of over 200 inches.

DIS Printing technology is capable of faithfully reconstructing the original masterpieces due to

a comprehensive examination of paint materials conducted with the aid and knowledge of experts in various fields.

This has enabled us to thoroughly reproduce the characteristics of the colors, lines, and textures of the originals, leading to an end product that is a significant improvement over conventional photographs, printings, and lithographs.

While making endeavors to enhance the DIS technology itself, we have achieved a wide variety of innovative projects, some of which are summarized in Figure 4- 8 below.

\subsection{Composition of the Bamiyan Virtual Museum}

- User-Friendly Interface -

Based on the research materials at Kyoto University, accumulated information was arranged and classified, associated with spatial and geographic reference point , and stored in different levels of the database.

For example, data on the West Great Buddha, Af- ghanistan, Bamiyan remains and the stone caves around the West Great Buddha, are all linked to each other. Data on other stone caves are stored together as a separate group.

In the museum, you can use these classification to quickly and easily, track down and select high-definition digital images .

The following is a basic description of the hardware for this museum system.

A computer is set up in the center with a touch panel that allows you to specify the section of the remains you wish to view, and a high definition display (for a clear view of the caves).

In the computer, DIS Soft Engine is loaded.

The engine carries out directions input from the touch panel, searching for pictures and displays them.

A touch panel is adopted to enable those who are not very familiar with the computer to search and retrieve information intuitively. The presence of several touchable areas on the panel improves the work efficiency. Area A shows the selected part on the map, from an overall view of the remains and, simultaneously, area E displays the Thumbnail List of research materials relevant to the selected part. If you select an image from the Thumbnail List, area A shows the magnified image with a supplementary map in area D and related information in area F. The supplementary map and Information are not displayed during the first step, the choosing of a position on the overall map, and so during that step, area A extends to cover over areas, D, E and F, to providing a larger view of the map. Area B shows the track of the retrieval track and you can return to any of the tracks you retrieved previously. Area $\mathrm{C}$ shows the Command buttons used to control the system itself, such as "shut down". The Command buttons change according to the contents of the other areas.

The following is an example of operation of the system.

Archived data can be selected by touching the panel, starting from the overall view of the remains as the Top Page, and gradually, focusing on a specific cave to reach the mural paintings related to that cave.

First, the upper part of the touch panel shows a full view of the caves. When you touch the part you want to examine more closely, it will be high-lighted and a magnified image of the area will be shown in the lower part of the screen.

For example, if the East Great Buddha is selected from the overall view of the remains on the upper part of the touch panel, the lower part, will display a magnified image of the East Great Buddha and its surroundings.

If you touch the East Great Buddha part within the 


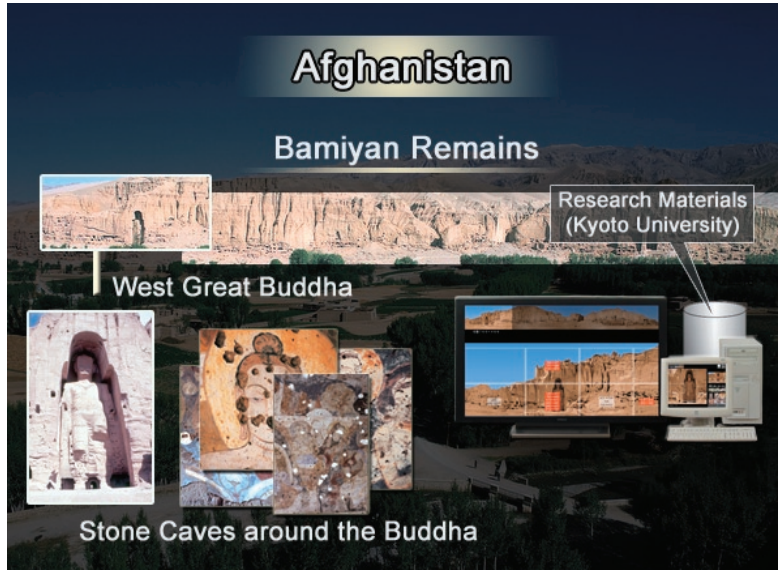

Fig. 4-9 Digital archive of research materials

High definition display

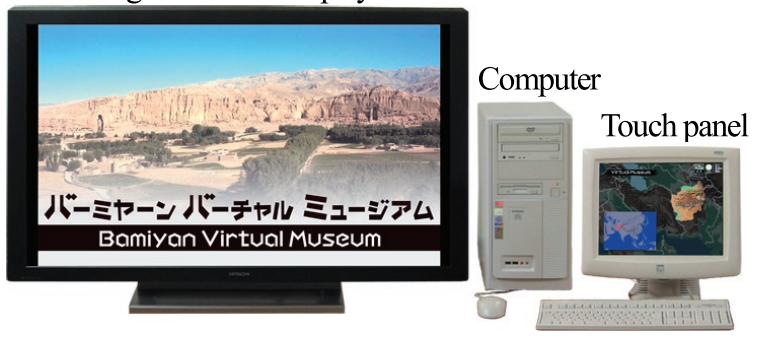

Fig. 4-10 The basic component

\begin{tabular}{|c|c|c|}
\hline B Retrieval tracks & C Command \\
\hline \hline $\begin{array}{c}\text { A } \\
\text { Positioning on map } \\
\text { or } \\
\text { Selected image }\end{array}$ & $\begin{array}{c}\text { D } \\
\text { Supplementary } \\
\text { map }\end{array}$ \\
& $\mathbf{E}$ \\
\hline F Information & \\
\hline
\end{tabular}

Fig. 4-11 Allocation of touchable area

section displayed, the image will be further magnified. If you touch the East Great Buddha within the image once more, you can see the list of mural paintings, etc. relevant to the East Great Buddha cave.

If you touch one of the mural paintings on the list, the selected image will be shown on both the touch panel and the large high-definition display. In the same way, other images can be selected and shown on the screen.

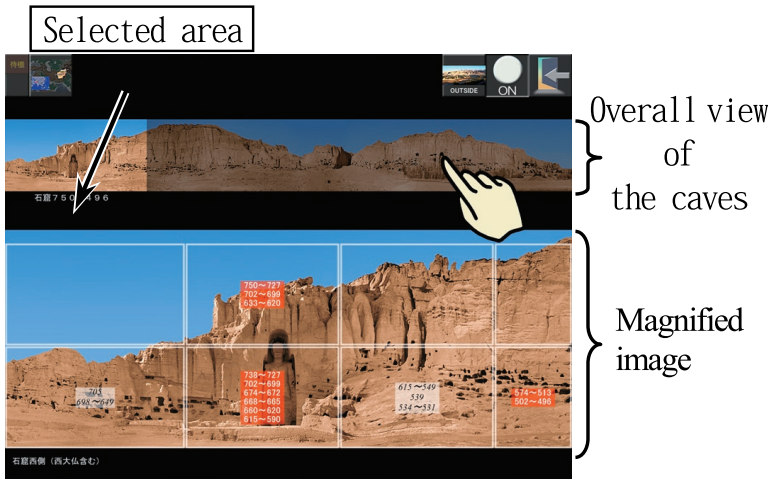

Figure 4-12 Overall view of the caves \& Magnified

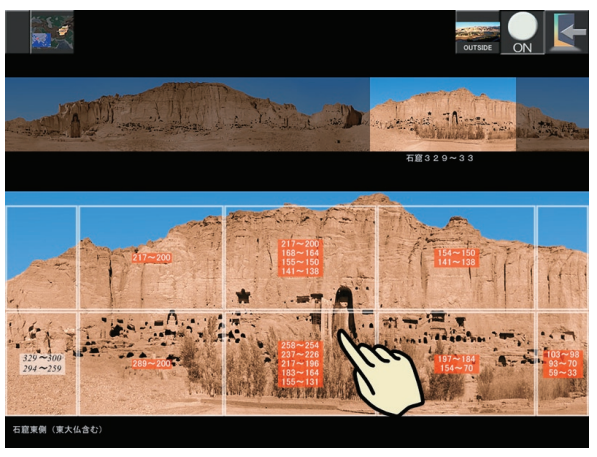

Fig. 4-13 Select the East Great Buddha

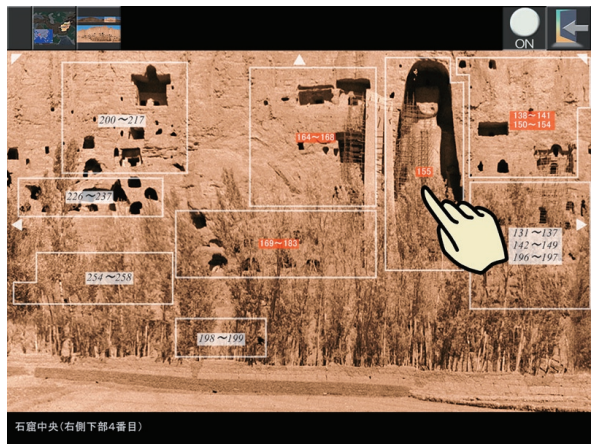

Fig. 4-14 Selecting the East Great Buddha

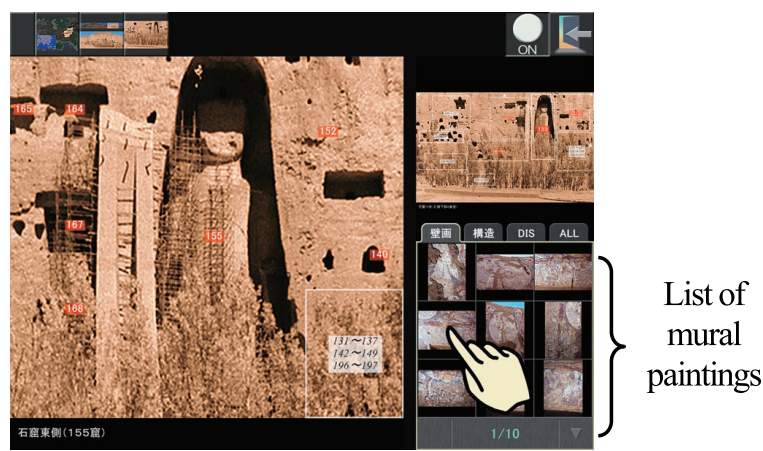

Fig. 4-15 Displaying the list of the mural paintings 


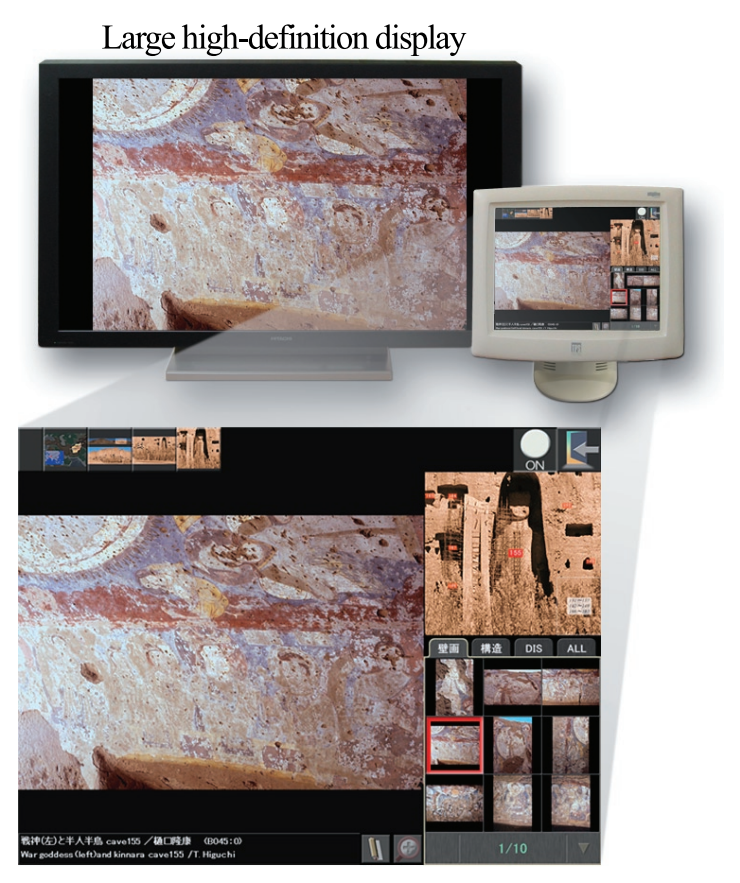

Fig. 4-16 Displaying the selected image

If you touch a part of the selected image, the display will magnify that part. You can also "drag" the image by dragging the magnified image. In such case, Area E shows the magnified image, with the dragging point highlighted in red.

The retrieval tracks listed in the top left section allows you to return to previous information you have retrieved, and to start a new search from there if you wish.

\subsection{Expansion of the system to cover other Silk Roads regions}

We plan to extend the Bamiyan Virtual Museum to cover the entire remains of Bamiyan artifacts scattered throughout Silk Road countries, and to make it available to more people via expanded network access, enabling researchers worldwide to exchange information through, and add information to the system. The archiving and sharing of such research results will help advance study of the Silk Roads regions.

\section{The Design of the DSR Portal \\ 5.1 Overview}

The portal site of the DSR (Digital Silk Roads) project (http://dsr.nii.ac.jp/) serves a repository of digital resources, the main contents of which are digital archives of rare books and endangered cultural heritage materials $[16,21]$. The purposes of the portal are to distribute research findings and to motivate informa-

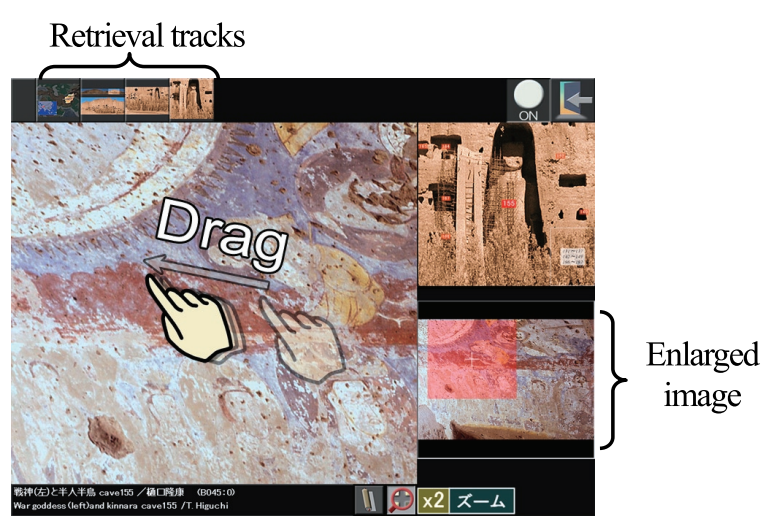

Fig. 4-17 Magnification of the selected image

tion exchange among researchers and non-experts alike, with its end goal being the creation of a comprehensive resource on the Silk Roads that is accessible from anywhere in the world via the Internet. To realize this goal, we have developed the portal based on standard technologies that do not require proprietary tools for development or viewing, and made it available to the public free of charge. This section introduces the contents of the DSR portal, how we are building the system, and the direction of future system development.

\subsection{The Contents of the DSR Portal \\ 5.2.1 General Information}

General information (Figure 5-1) introduces project information, an overview of the DSR project, and summaries of the DSR symposiums held in Tokyo in 2001 and Nara in 2003. This page is also a portal to other contents such as:

- Digital Archive of Toyo Bunko Rare Books (Section 5.2.2)

- The Citadel of Bam, Iran: Keeping Memories and Gathering Information for Post-earthquake Reconstruction (Section 5.2.3)

- Bamiyan Virtual Museum (Section 4)

- Advanced Scientific Portal for International Cooperation on Digital Silk Roads (Chapter 6)

\subsubsection{Digital Archive of Toyo Bunko Rare Books}

"Digital Archive of Toyo Bunko Rare Books" (Toyo Bunko Web) (http://dsr.nii.ac.jp/toyobunko/) is a portal site of rare books about the Silk Roads (Figure 5-2). This is a collaborative project with Toyo Bunko (Oriental Library), the detail of which was addressed in Section 3. The design philosophy of Toyo Bunko Web is to improve accessibility to both the textual and image contents of their books through digitization and information extraction from books for navigation and in- 